\title{
Relasi Kuasa antara Muslim Ortodoks dan Penghayat Kaweruh Kamanungsan di Banyuwangi dalam Perspektif Ideological State Apparatus Louis Althusser
}

\author{
Lia Hilyatul Masrifah \\ Universitas Bakti Indonesia (UBI), Banyuwangi \\ liahilyatulm93@gmail.com
}

\begin{abstract}
This article attempts to scrutinize the relation between Orthodox Muslim and the followers of Kawerub Kamanungsan in Sedoyo, Banyuwangi, East Java. These two religious groups that have two different and opposite ideological perspectives, apparently, have influenced cultural and structural agencies in the village. Having utilized Althusser's Ideological State Apparatus, the elites of these groups are competing each other to introduce their own ideologies into social institutions like religion, education, family, and legal instruments. As a result, village structures are divided into Muslim and Kaweruh Kamanungsan groups. Evidently, Muslim groups who have vertical link into government and horizontal one into society succeeded to eliminate "deviant" local tradition groups. However, Kawerub Kamanungsan, as one of local tradition in this village, has survived from the proselytizing program and has successfully built a bridge to eliminate the gap between religious and cultural differences in society.
\end{abstract}

Keywords: Ideology, Religion, Village Government, Kaweruh Kamanungsan, Orthodox Muslim. 


\section{Pendahuluan}

Blambangan ${ }^{1}$ adalah sebutan lama dari kota Banyuwangi. Dalam catatan sejarah, Banyuwangi termasuk daerah yang terbebas dari Islam, yang ada kepercayaan lokal dan agama Hindu yang menjadi agama mayoritas. Letak geografis yang tidak jauh dari pulau bali, membuat orang-orang bali menggunakan Blambangan menjadi kawasan penyangga untuk melawan ekspansi dan konsolidasi Islam yang diinisiasi oleh Mataram Islam. Sejarah perjalanan panjang Banyuwangi sampai pada "islamisasi Jawa" yang telah masuk pada kawasan ini, kemudian muncul pergulatan-pergulatan kecil antara Islam dan agama lokal atau sekarang lebih sering disebut sebagai penghayat kepercayaan lokal, dan menjadi sebuah kajian yang menarik untuk ditelusuri lebih dalam dan spesifik. Ada beberapa peneliti yang telah mengkaji tentang keagamaan yang ada dalam masyarakat Jawa, yaitu Geertz, Hefner, Beatty, Kuntjaraningrat, dan Budiwati yang menjelaskan bahwa ada pertemuan yang unik antara agama Islam, agama lokal dan budaya lokal. Dari sudut pandang antropologi, Geertz menjelaskan tentang agama Islam yang ada di Jawa, dia menyatakan bahwa Islam yang berkembang di Jawa adalah Islam yang mudah menyesuaikan diri, menyerap, dan bersifat pragmatis dan menempuh cara yang berangsur-angsur. ${ }^{2}$ Mengadakan kompromikompromi parsial, dan perjanjian yang setengah-setengah, hasilnya adalah Islamisme yang tidak berpretensi sebagai ajaran yang murni dan komprehensif. Tidak memiliki semangat yang berkobar-kobar, melainkan memiliki semangat yang toleran.

Agama atau kepercayaan yang disinyalir sudah ada sebelum terbentuknya Negara Republik Indonesia, terkadang disebut agama lokal ${ }^{3}$

\footnotetext{
1 "Kata Blambangan" orang lebih mengenalnya dalam dongeng atau teater rakyat. Terkenal sebagai negeri antah berantah yang dipimpin oleh seorang raja bernama Minak Jinggo dan menjadi musuh besar kerajaan Majapahit pada masa itu. Untuk sejarah lengkapnya lihat buku Margana: 2012.

${ }^{2}$ Geertz, Clifford. Islam Observed (New Haven: Yale University Press, 1968), 16.

${ }^{3}$ Hasse, J., Bernard Adeney Risakotta, dan Zainal Abidin Bagir. "Diskriminasi Negara Terhadap Agama Di Indonesia; Studi atas Persoalan Posisi Hukum Towani Tolotang Pasca Pengakuan Agama Resmi”, dalam Jurnal Kawistara, Vol. 1. No. 2, 2011.
}

66 | Lia Hilyatul Masrifah - Relasi Kuasa antara Muslim Ortodoks dan Penghayat Kaweruh Kamanungsan 
atau agama tradisional ${ }^{4}$ dalam penelitian ini penulis akan menggunakan agama lokal untuk menyebut kepercayaan yang dianut oleh penganut kebatinan Kawerub Kamanungsan. Di mana para penganut agama lokal ini dalam perkembangannya mengalami berbagai problem yang tidak lepas dengan legitimasi tentang agama resmi dan berbagai praktik keagamaan yang dicekal. Penelitian Ibnu Qoyim ${ }^{5}$ misalnya, membahas mengenai berbagai masalah yang dihadapi beberapa kelompok agama lokal di Indonesia, yaitu Tengger, Parlamin, Badui, Towani, Tolotang dan Patuntung, kelompok-kelompok tersebut dalam sejarahnya mengalami berbagai tindakan diskriminasi, seperti tidak adanya kebebasan dan pembatasan gerak dalam menjalankan ajaran, maupun formalisasi agama mereka dalam agama resmi.

Pada kurun waktu 2005-2007, Yayasan Interseksi menerbitkan dua buku ${ }^{6}$ yang membahas mengenai permasalahan yang juga dihadapi oleh beberapa agama lokal. Yayasan ini menyebutkan istilah yang berbeda untuk agama lokal tersebut. Yaitu istilah komunitas dan kelompok minoritas. Agama-agama lokal yang disebut sebagai kelompok minoritas itu juga diberitakan menghadapi berbagai masalah dalam perjumpaannya dengan Negara maupun lingkungannya. Orang Dayak Pitap, Orang Wana, orang Sedulur Sikep, Wetu telu di Lombok juga mengalami diskriminasi dalam bentuk konversi ke dalam agam resmi, sehingga jumlah mereka diberitakan mengalami penurunan yang signifikan. Kanveruh Kamanungsan juga tidak lepas dari pencekalanpencekalan dalam melaksanakan peribadatan keagamaan mereka. Pendopo $^{7}$ tempat mereka melakukan peribadatan ditutup dengan berbagai alasan salah satunya ialah adanya anggapan tentang aliran sesat dan tidak ada pengakuan Negara tentang agama lokal ini. Lalu bagaimana

\footnotetext{
${ }^{4}$ Budiwanti, Erni. Islam Sasak: Wetu Telu versus Waktu Lima (Yogyakarta: LKiS Pelangi Aksara, 2000), 45.

5 Ibnu Qoyim, Agama dan Pandangan Hidup masyarakat Towani Tolotong, dalam http://elib.pdii.lipi.go.id/katalog/index.php/serachkatalog/byId/6295/ diakses 31 Oktober 2013.

${ }^{6}$ Masing-masing buku Hak Minoritas: Dilema Multikulturalisme di Indonesia (2005), dan buku Hak Minoritas: Multikulturalisme dan Dilema Negara Bangsa (2007).

7 Pendopo adalah tempat ibadah, istilah yang digunakan oleh penganut agama lokal Kawerub Kamanungsan dalam berkumpul dan melalukan ritual kepercayaan mereka.
} 
sebenarnya pengakuan negara terhadap agama-agama lokal? Indonesia adalah negara Pancasila yang berdasarkan ketuhanan Yang Maha Esa, di mana semua pemeluk agama harusnya diperlakukan sama sebagai warga Negara. ${ }^{8}$ Namun, bila dilihat kondisi saat ini negara secara formal hanya mengakui enam agama, yakni Islam, Kristen, Katolik, Hindu, Budha dan Konghucu. Dengan demikian agama-agama tersebut memiliki representasi di Kementerian Agama baik ditingkat pusat maupun daerah. Agama-agama tersebut juga dengan leluasa dapat melaksanakan ajaran agama, ibadah maupun perayaannya.

Pengakuan negara terhadap agama tertentu yang disebut sebagai agama dunia (world religion) menyebabkan agama-agama lokal sering mengalami penindasan, selalu dalam posisi termarginalkan, tersudut antara lain melalui pemaksaan untuk memeluk suatu agama dan kepercayaan tertentu untuk mendapatkan identitas resmi dan dijamin dalam hukum sebagai warga negara. Kebijakan Negara melalui regulasinya bahkan dikatakan menyebabkan semakin punahnya agamaagama lokal tersebut. Desa Sedoyo terkenal sebagai desa adat dengan masyarakat yang religius dan memiliki tradisi keagamaan yang unik memberikan daya tarik yang lebih bagi peneliti dan wisatawan luar maupun lokal.

Kita tahu bahwa secara umum, dalam masyarakat yang religius, para pemuka agama memainkan peran yang sangat signifikan dalam berbagai spektrum sosial. Mereka merupakan elite masyarakat yang dapat mendominasi berbagai macam keputusan-keputusan sosial yang dilakukan oleh para pihak yang terlibat dalam komunitas tertentu. Sepak terjang mereka (elite masyarakat) yang dominan dan hegemonik dalam panggung sosial, menstimulasi berbagai kalangan ilmuan sosial untuk menelaahnya dengan berbagai macam perspektif. Para elite yang memiliki kekuasaan dan menggunakan kekuasaannya untuk tujuan dan kepentingan tertentu. Dalam rangka mengakumulasi kekuasaan mereka mencari legitimasi dari nilai-nilai tradisional yang hidup dalam image kultural mereka. Akan halnya masyarakat Jawa kontemporer, ada kecenderungan untuk mencoba mengambil nilai-nilai publik yang

8 Nasaruddin Umar, Antara Negara dan Agama Negara,
http://kemenag.go.id/file/dokumen/AntaraNegara/ diakses 31 Oktober 2013.

68 | Lia Hilyatul Masrifah - Relasi Kuasa antara Muslim Ortodoks dan Penghayat Kaweruh Kamanungsan 
bersumber dari agama. Agama yang penuh simbol dan kode ritual yang bermuatan transendental diambil sebagai atribut baru bagi elite-elite politik dan juga kelas menengah. Desa Sedoyo misalnya, para pemimpin adat dan agama memiliki kekuatan untuk memainkan peran sebagai elite dalam masyarakat. Mereka memiliki kharisma karena dianggap sebagai orang yang lebih mengerti tentang agama, budaya dan sejarah diwilayah Sedoyo. Pengkultusan yang diawali dari adanya garis keturunan nenek moyang dan dianggap sudah lebih dekat dengan Tuhan Yang Maha Esa, serta lebih mengerti tentang hal-hal yang berkaitan dengan mistisisme.

Masih terbilang jarang penelitian tentang hubungan yang terjalin antara penganut agama lokal Kaweruh Kamanungsan dengan komunitas muslim. Penjelasan tentang bagaimana kehidupan sehari-hari mereka, tentang perubahan sosial-budaya yang melibatkan keduanya dan para pemimpin terkait, yang pada akhirnya menimbulkan adanya perbedaan keterlibatan mereka dalam hal politik, ekonomi dan budaya, dan tentang posisi keduanya dalam struktur masyarakat. Dari latar belakang di atas, bisa kita lihat bahwa jika di sebuah lingkungan terdiri dari masyarakat yang beragama Islam dan agama lokal, akan menjadi menarik saat kita mencoba melihat bagaimana kehidupan sosial mereka, kemudian dengan adanya perbedaan itu apakah ada faktor historis yang mempengaruhi bagi keduanya dalam menjalin relasi.

Berangkat dari latar belakang masalah di atas, artikel ini dimaksudkan untuk melihat secara lugas dan gamblang terkait dengan isu sosial yang ditimbulkan oleh kedua organisasi tersebut. Lebih tepatnya artikel ini ingin menjawab pertanyaan tentang mengapa perbedaan keyakinan dan ideologi berpengaruh pada keterlibatan mereka dalam struktur kelembagaan desa?

\section{Keterlibatan Penghayat Kaweruh Kamanungsan dan Muslim dalam Dunia Sosio-Politik}

Desa Sedoyo termasuk desa yang memiliki pola masyarakat agraris di mana struktur sosial masyarakat agraris bukan hanya secara relatif bersifat tertutup, melainkan juga tetap terikat pada nilai dan elite lokal tradisional. Hubungan diadik elite-massa yang dalam batas tertentu 
bersifat magis tidak serta merta menjadi cair dengan masuknya alat-alat komunikasi modern tersebut. Pada saat yang sama berbagai persoalan, ekonomi, sosial, politik dan moral yang muncul akibat serbuan media dan teknologi modern tidak terselesaikan oleh sistem demokrasi yang juga menyerbu kawasan tradisional.

Dinamika Politik Keagamaan di Sedoyo Perubahan tata sosial dan politik, baik akibat globalisasi ataupun akibat reformasi, terutama Otonomi Daerah dan Demokratisasi, paling dirasakan oleh masyarakat di Pedesaan. Hal ini membuat tata nilai lama mengalami degradasi yang semakin cepat, termasuk nilai-nilai yang bersumber dari ajaran agama yang selama ini menjadi tempat berlindung pemeluknya dan memberi kedudukan khusus bagi elite lokal dengan segala keuntungan sosial, ekonomi, politik dan teologisnya. Oleh karena itu, simbol-simbol keagamaan yang paling mudah dieksploitasi bagi tujuan-tujuan politik jangka pendek akan menjadi wilayah yang paling rawan di daerah pedesaan dan bagi masyarakat yang masih terikat pada sumber informasi tunggal. Seluruh informasi yang masuk dalam kehidupan publik mudah ditafsir oleh elite lokal secara sepihak dan disosialisasikan melalui media tradisional seperti khotbah-khotbah keagamaan dan semacamnya.

Pola hubungan kliental elite lokal dan warga yang diadik ataupun magis masih merupakan akar fundamental bagi kehidupan masyarakat Sedoyo dan komunitas keagamaan yang sama sekali belum dapat dicairkan oleh pola hubungan baru yang lebih rasional dan pragmatis. Sehingga jika ada ide-ide demokrasi harusnya disesuaikan dengan kepentingan lokal dan memiliki akar tradisional yang karismatik. Proses sosial-politik dalam kehidupan masyarakat Sedoyo, bagaimana seseorang dipilih sebagai pemimpin organisasi sosial dan keagamaan, partai, ketua RT, anggota BPD hingga kepala desa, berhubungan dengan banyak faktor. Selama ini, hubungan kekerabatan, penguasa tanah, dan tokoh agama, secara bersama atau sendiri, memegang dominasi proses sosialpolitik di pedesaan.

Kita umumnya dapat langsung mengenali ideologi religius, ideologi etis, ideologi legal, ideologi politik, dan lain-lain-deretan panjang 'pandangan dunia'. Tentu saja, sekalipun dengan berasumsi bahwa kita menjalani salah satu ideologi tersebut sebagai kebenaran

70 | Lia Hilyatul Masrifah - Relasi Kuasa antara Muslim Ortodoks dan Penghayat Kaweruh Kamanungsan 
(misalnya 'iman' pada Tuhan, tugas, dan keadilan dan sebagainya). Indonesia terutama para elitnya sangat memikirkan masalah ideologi. Selama hampir tiga puluh tahun Orde Baru telah memiliki suatu dasar Negara ideologis yang tertanam dalam undang-undang dasar dan melarang ideologi lainnya karena kekhawatiran kaitannya "primordialprimordial" dari ideologi-ideologi tersebut dengan masyarakat. ${ }^{10}$ Persepsi-persepsi elite tentang munculnya kembali ideologi-ideologi swasta yang "berbahaya" memang benar-benar ada. Para perwira militer, birokrat senior, Abdurrahman Wahid, kaum nasionalis sekuler, kaum demokrat dan para intelektual non-Muslim melihat adanya kebangkitan kembali pertentangan-pertentangan ideologi pada tahun-tahun belakangan.

Saling hubungan antara kepercayaan agama dan perilaku politik dianggap sedemikian jelasnya, bagaimana keduanya memiliki peranan penting pada sebuah pemikiran seseorang. Seorang yang yakin dengan kepercayaannya akan memperlihatkan sikap dan pemikiran yang tidak lepas dari ajaran agama dan ideologinya. Wajar halnya dalam perilaku politik seseorang memperlihatkan kepiawaiannya dalam berperilaku dengan landasan ideologinya. Di sepanjang skema ini, kita mengamati bahwa representasi ideologi yang ideologis sendiri dipaksa untuk mengakui bahwa setiap 'subjek' diberkahi dengan sebuah 'kesadaran', dan percaya pada ide-ide yang di inspirasikan dari 'kesadaran' di dalam dirinya itu. ${ }^{11}$ Dan masing-masing perangkat kepercayaan agama punya perangkat organisasinya tersendiri- partai politik, perhimpunan, organisasi dan seterusnya, dalam padangan Geertz, orang-orang yang menganut kepercayaan agama tertentu akan membentuk suatu aliran sosio-politk yang akan menggantikan ikatan-ikatan tradisional dan memperkuat kembali struktur desa. ${ }^{12}$ Ikatan-ikatan "kesamaan pikiran

9 Louis Althusser, Tentang Ideologi: Marxisme Strukturalis, Psikoanalisis, Cultural Studies (Yogyakarta: Jalasutra, 2008), 45.

${ }^{10}$ Ramage Douglas, Percaturan Politik di Indonesia: Demokrasi, Islam, dan Ideologi Toleransi, terj. Hartono Hadikusumo (Yogyakarta: Mata Bangsa, 2002), 336.

${ }_{11}$ Althusser, Tentang Ideologi, 45.

12 Clifford Geertz, "Form and Variation in Balinese Village Structure", dalam American Anthropologist, Vol. 61, No. 6 (1959), 991-1012. 
ideologis" in ${ }^{13}$ memberikan tenaga kepada aliran yang berbeda menjadi para peramal keterikatan pribadi lebih perkasa ketimbang kedudukan struktur sosial lokal. ${ }^{14}$ Secara ringkas, gerakan-gerakan politik di Jawa memperlihatkan telah muncul suatu perpecahan dini antara sektor-sektor politik ortodoks dan sekularis, perpecahan itu secara organisasi dan ideologi meliputi seperangkat pokok permasalahan yang berpusat pada ortodoksi lawan bukan ortodoksi di dalam Islam, perpecahan keorganisasian telah memperlihatkan suatu ketahanan yang luar biasa dan kemantapan di dalam politik Jawa. Kendati ada sejumlah besar variasi faktor-faktor sejarah yang digergaji.

Di Sedoyo, adapun perbedaan yang terjadi antara mereka (Kawerub Kamanungsan dan Islam) dibangun dalam ruang yang sama, sehingga intensitas lebih besar dalam kehidupannya. Muslim yang taat, saat menggelar sajadah di depan umum mengetahui benar bahwa tetangganya atau orang yang di sekitarnya tidak menghiraukan panggilan salat. Kawerub Kamanungsan menjadi kelompok mistik yang lebih sering berkumpul dimalam hari dengan berdiskusi dengan makna ini atau makna itu seolah-olah dirancang untuk mengganggu—meski tidak berarti menyerang-penganut muslim taat yang tinggal di sebelah rumah. Dan hal tersebut terjadi di setiap harinya tanpa menghiraukan satu sama lain.

Sejak awal pemerintahan dan kepemimpinan yang ada di Sedoyo telah diwarisi tradisi tentang kepemimpinan yang didasarkan dalam beberapa kriteria seperti harus keturunan asli orang Osing dan berpengetahuan luas, berpendidikan tinggi serta memiliki kedekatan emosional tersendiri pada masyarakat. Dan berpendidikan tinggi itulah yang mempengaruhi kenapa sampai saat ini anggota Kaweruh Kamanungsan tidak dapat melibatkan dirinya pada struktur kelembagaan desa. Anggota Kaweruh Kamanungsan lebih banyak yang tidak menyelesaikan wajib sekolah 9 tahun. Jika pun ada itu hanya sedikit dan bisa dihitung jari. Hal ini disebabkan oleh perekonomian yang tidak mendukung serta pemahaman tentang kehidupan yang dimaknai begitu dalam hingga lebih terlihat berspekulasi dalam menjalani hidup. Muslim

13 Clifford Geertz, "Ritual and Social Change: a Javanese Example", dalam American Anthropologist, Vol. 59, No. 1 (1957), 32-54.

${ }^{14}$ Geertz, Form and Variation in Balinese Village Structure, 991-1012.

72 | Lia Hilyatul Masrifah - Relasi Kuasa antara Muslim Ortodoks dan Penghayat Kaweruh Kamanungsan 
taat yang memiliki pemikiran lebih realistis dan menjadikan pendidikan sebuah kewajiban memiliki peluang lebih besar dalam keterlibatannya distruktur kelembagaan. Persinggungan secara anarkis tidak pernah terjadi di desa ini melainkan lebih terlihat bagaimana keduanya memerankan peran dan posisi mereka masing-masing.

Ideologi yang diyakini ini mempengaruhi pola perilaku dan berfikir penghayat kebatinan yang idealnya hidup bertetangga dengan reputasi yang baik seharusnya mereka tidak merasa khawatir tentang perbedaan ideologi. Kompromi-kompromi yang seharusnya telah melebur sebagai sebuah masyarakat yang majemuk dimunculkan. Tidak terjadi malah yang terlihat jelas ialah tentang perbedaan Ideologi yang tampak antara keduanya. Ketegangan yang mudah dipahami dengan didasari Ideologi dan keyakinan keagamaan antara Muslim (ortodoks) dan penghayat kebatinan Kawerub Kamanungsan.

\section{Perbedaan Keterlibatan Muslim dan Penghayat Kebatinan Kaweruh Kamanungsan dalam Struktur Masyarakat}

Aktor-aktor yang terlibat, Kita akan mulai dengan pemetaan aktor yang berperan dalam struktur masyarakat Sedoyo. Pertama, elite lokal yang terdiri dari sesepuh adat Osing dan pimpinan desa (lurah dan seperangkatnya). Kedua, elite keagamaan dan orang yang berpendidikan tinggi. Ketiga, dan yang terakhir ialah "wong cilike" yaitu mereka yang tidak berpendidikan tinggi serta bukan orang yang tersusun dalam struktur perangkat desa, melainkan dia lebih banyak terlibat dalam lembaga adat. Yang pada dasarnya pengertian elite dalam pembahasan kali ini adalah orang-orang yang memiliki pengaruh serta mendapatkan status dan kedudukan lebih tinggi dalam kehidupan masyarakat.

Definisi Althusser dengan ISA (Ideological State Apparatus) mampu membawa kita lebih mudah untuk mempelajari tentang sebuah struktur dan hubungan ideologi pada identitas individu. Ideologi yang masuk melalui program-program televisi swasta dan program desa misalnya, media yang memiliki pengaruh besar pada pemikiran dan tindakan seseorang mampu mengorganisir atau mengontrol ideologi secara tidak langsung, diperkuat dengan bagaimana para pemimpin desa (elit desa) 
dan anggotanya melakukan kajian rutin di desa mengenai isu-isu terkini tentang sosial politik keagamaan, yang bagaimanapun keadaannya, hal ini sangat dinamis dan proses yang terus menerus akan direproduksi dan disusun kembali menjadi sebuah praktik, mempengaruhi bagaimana cara seseorang berpikir, bertindak dan memahami diri sendiri dan hubungan seseorang dengan masyarakat. Bertindak karena ia bertindak oleh sebuah sistem. ${ }^{15}$

\section{Gambar 1.}

Klasifikasi penguatan ideologi oleh Kawerub Kamanungsan dan Muslim Ortodoks

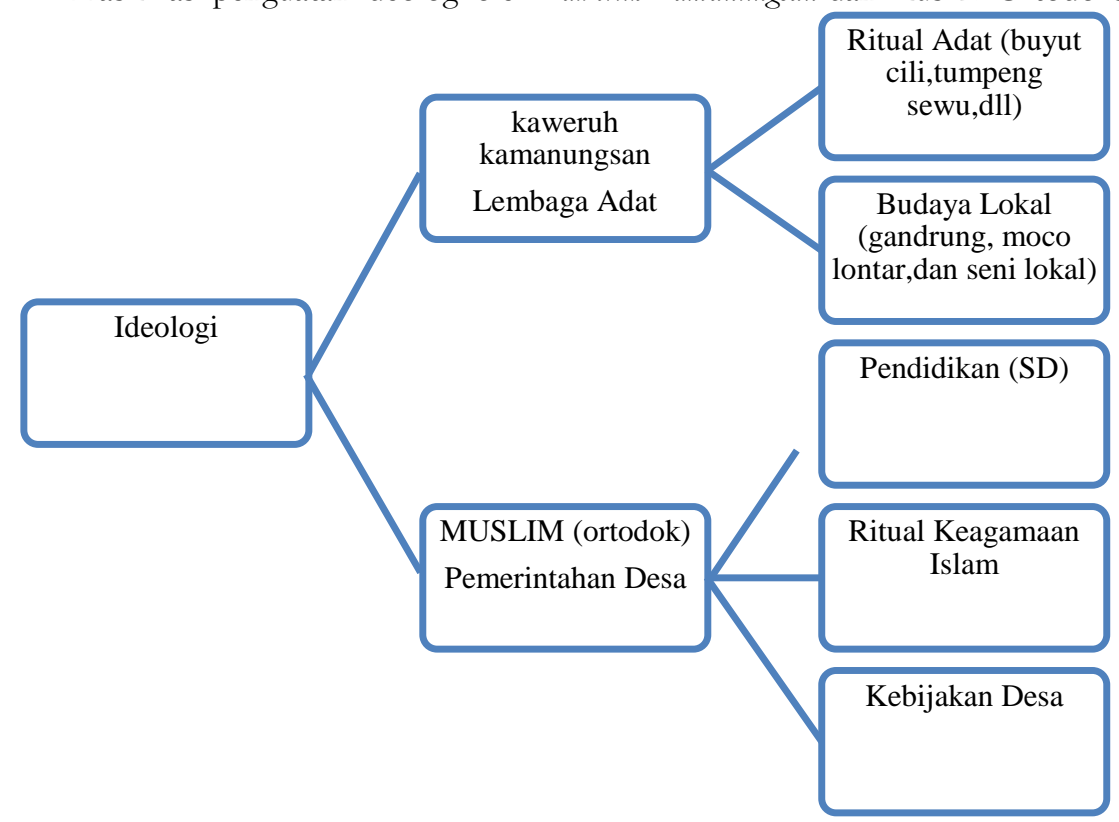

Dua pembagian yang berbeda bagi keduanya dalam menunjukkan ideologi, seperti kita lihat pada bagan di atas. Kawerub Kamanungsan menempatkan dirinya pada sebuah lembaga adat dan ritual keagamaan tradisional, mudah bagi mereka menunjukkan ideologi karena lebih dekat dengan masyarakat dan berkaitan dengan kehidupan mereka sehari-hari. Muslim Ortodoks ada pada pemerintahan desa dan pendidikan sekolah dasar. Pengelompokan tersebut dapat menggambarkan bahwa aliran

15 Louis Althusser, Ideological State Aparatus (New York, NY: W.W. Norton and Co., 2003), 693-702.

74 | Lia Hilyatul Masrifah - Relasi Kuasa antara Muslim Ortodoks dan Penghayat Kaweruh Kamanungsan 
ideologi yang berkembang di masyarakat Indonesia itu mengikuti jalur religius-sekuler dalam menentukan ideologi yang mereka anut agar mendapat dukungan dari masyarakat yang satu aliran. Ideologi yang mampu menjadi dasar solidaritas sosial yang dibutuhkan untuk melakukan perubahan, dan ideologi juga akan menjadi awal perubahan saat menyoroti perbedaan dan permasalahan yang ada pada masyarakat. Perubahan struktur ekonomi yang terjadi di daerah ini juga bisa menjadi penyebab perubahan dalam hubungan antar individu.

1. Aktualisasi Ideologi Berasaskan Syariat Islam dalam Pendidikan Dasar dan Kebijakan Pemerintah Desa.

Pertanyaan tentang Mengapa dan bagaimana agama mempengaruhi keterlibatan seseorang dalam sosio-politik telah menjadi perbincangan panjang bagi para ahli akademisi sebelumnya. Bagaimana pengaruh agama atas budaya sosio-politik tergantung pada pentingnya peran agama dalam masyarakat. Bila dirasa penting oleh seseorang, agama dapat mempengaruhi cara pandang dan penilainya atas aspekaspek kehidupan, semakin tinggi pula ia memandang agama dalam kehidupan, semakin tinggi pula ia memandang aspek-aspek kehidupan dalam perspektif agama yang diyakininya, pengaruh agama terhadap politik terletak pada sifat dasar agama itu sendiri, yakni agama "sebuah sistem simbol yang membentuk kegairahan (moods) dan motivasi yang kuat, besar, dan berjangka panjang dalam kehidupan manusia dengan merumuskan konsepsi-konsepsi tersebut dengan sebuah aura faktualistas sedemikian rupa sehingga tampak bahwa kegairahan dan motivasi tersebut benar-benar nyata". Tentang adanya agama dan politik yang berinteraksi jelas karena berkaitan dengan kegairahan, motivasi dan kepentingan manusia.

\section{Gambar 2.}

Hubungan Muslim, Ideologi, dan Struktur

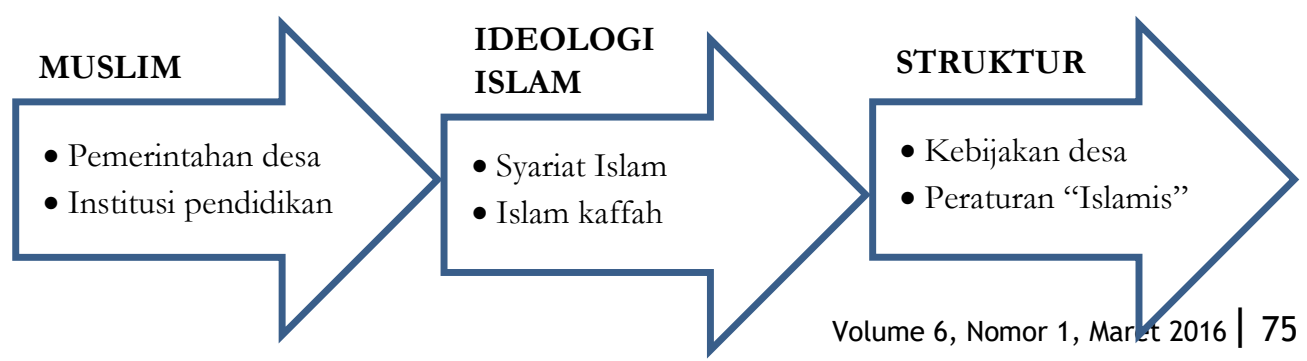


Seorang pemimpin dalam masyarakat Sedoyo memiliki aturanaturan tersendiri seperti penguasaan spiritual. Seperti halnya masyarakat Jawa kontemporer, dalam pembahasan sebelumnya juga telah disinggung tentang ada kecenderungan untuk mencoba mengambil nilai-nilai publik yang bersumber dari agama, yang penuh simbol dan kode ritual yang bermuatan transendental diambil sebagai atribut baru bagi tidak saja eliteelite politik tetapi juga kelas menengahnya. Berbagai ritual keagamaan maupun kelembagaan seperti ikatan-ikatan yang didasari oleh agama pun menjadi simbol-simbol yang menopang kedudukan, profesi, jabatan dan bahkan juga kekuasaan mereka. namun demikian, simbol subjektif elit itu mempengaruhi perubahan masyarakat yang mendukungnya, sehingga yang tersebut belakang ini tetap dalam posisi lemah yang tidak memiliki bargaining poisition dalam formasi sosial, secara struktural, ekonomi, maupun politik. Dalam posisi ini agama menjadi sekedar instrumen adaptasi terhadap nilai-nilai eksternal yang dihadapi elite politik, tanpa harus menjadikan yang bersangkutan menggadaikan nilai-nilainya sendiri untuk mengubah dunia eksternal. Dengan kata lain, agama dijadikan instrumen dominasi atas masyarakat. Keterlibatan Muslim ortodoks dalam pemerintahan desa dan sekolah dasar memberikan pengaruh penting dalam sebuah kebijakan dan tingkat pengetahuan masyarakat dalam keagamaan, seperti dalam tahap pendidikan dasar, SD Sedoyo memiliki tenaga kerja kurang lebih 10 guru pendidik dan hal itu diisi oleh Muslim Ortodoks.

Penerapan kebijakan sekolah tentang pelajaran agama Islam dan membiasakan peserta didik untuk mengikuti syariat Islam secara penuh. Seperti adanya penerapan syariat Islam yang diaplikasikan di tingkat kebijakan-kebijakan publik yang dibuat oleh pemerintahan desa, bahwa untuk siswa SD harus memiliki kemampuan membaca Alquran dan menganjurkan agar siswa yang beragama Islam mengenakan seragam dengan ketentuan yang menutup aurat. Sebagai landasan formal mereka menggunakan PERDA Banyuwangi sebagai dasar kuat dalam menanamkan nilai-nilai keagamaan: 
"Pasal 13 ayat 1 (a) bahwa Pendidikan pada SD/MI atau bentuk lain yang sederajat berfungsi: menanamkan dan mengamalkan nilai-nilai keimanan, akhlak mulia, dan kepribadian luhur;"”

Nilai-nilai dari ajaran agama Islam telah ditanamkan sejak dini akan menghilangkan kekhawatiran tentang berkembangnya kepercayaan lokal yang telah mengakar dalam sejarah panjang Sedoyo. Karakter orang Sedoyo yang sedikit keras dengan prinsipnya membuat para elite keagamaan dan pemimpin desa memutuskan untuk menanamkan nilainilai ajaran Islam sejak dini. Karena, dalam kehidupan masyarakat ini, orang tua dan guru merupakan sumber pengajaran utama. Cara mereka memberikan pelajaran kepada yang lebih muda atau anak-anak, antara lain dengan jalan menceritakan kisah leluhur dengan menggunakan folklore, atau dengan segala macam larangan yang dipandang tabu atau durhaka serta tentang ajaran agama.

Sebagaimana yang disebutkan di atas, kebijakan-kebijakan pemerintah desa Sedoyo dalam perkembangannya dijadikan sebagai kebijakan-kebijakan 'Islamis', pembentukan peraturan baru berdampak pada perempuan yang bekerja di pemerintahan desa dan pendidik menggunakan langkah-langkah simbolis ideologi 'islamis' yang dianjurkan mengenakan jilbab dan merupakan seragam sekolah bagi guru perempuan. Dengan lain ungkapan bahwa kebijakan tersebut berdiri di atas kepentingan umat Islam semata benar adanya. Dari kebijakan inilah pada aras lokal memperlihatkan adanya indikasi bahwa syariat Islam diberlakukan dalam wilayah hukum positif. Di Sedoyo, kelompok Muslim Ortodoks ini memiliki kecenderungan Islam yang berafiliasi secara kultural kepada organisasi NU dan kebanyakan konstituennya ke partai PKB.

Motivasi atau latar belakangi elite keagamaan dan pemerintahan desa mengusung isu penerapan syariat Islam dalam arena politik lokal jelas dengan berbagai alasan dan pertimbangan, pertama, mendapat motivasi ideologis, yang dimaksud bahwa penerapan syariat Islam mendapat justifikasi QS. Al-Baqarah [2]:208, "udkhulû fî al-slimi kâffab” (masuklah kamu kepada Islam secara total). Hal ini dipahami sebagai pintu gerbang penerapan syariat Islam baik dalam kehidupan bermasyarakat maupun bernegara. Kedua, kondisi sosial-keagamaan yang 
ada di Sedoyo memberikan dampak negatif pada perkembangan generasi selanjutnya. Bahwa kepercayaan lokal yang mistik dan spekulatif dikhawatirkan akan mempengaruhi pola pikir generasi selanjutnya dan tidak mampu mengambangkan desa Sedoyo dengan pola pikir yang realistis-agamis.

Selanjutnya kebijakan pemerintahan Desa yang membekukan kegiatan keagamaan Kawerub Kamanungsan dan pendopo tempat biasanya Kawerub Kamanungsan menjalankan peribadatan dinonaktifkan selamanya, meskipun Kaweruh Kamanungsan memiliki lebih dari 100 anggota resmi di Desa Sedoyo. Peneliti dalam hal ini tidak memiliki dokumentasi gambar saat dibekukannya Kawerub Kamanungsan karena ini telah terjadi pada tahun 2000-an dan saat itu tidak ada pemberontakan yang sifatnya anarkis pada saat penutupan. Yang ada hanya saksi hidup yang masih bertahan dalam ajaran Kaweruh Kamanungsan dan beberapa orang kelurahan yang terlibat saat itu.

Ada beberapa hal yang menjadi alasan pembekuan Kaweruh Kamanungsan. Pertama, Elite keagamaan (Muslim) yang pada saat itu menjabat sebagai lurah menemukan indikasi-indikasi kesamaan ajaran dengan paham Sapta Dharma yang telah dibekukan sebelum Kaweruh Kamanungsan, dengan diketahuinya cara beribadah menghadap ke timur matahari yang menggunakan kain kafan, sedangkan Kaweruh Kamanungsan tidak ada peribadatan yang pasti, itulah yang menjadi kelemahan ajaran kejawen sinkretis. Kawerub Kamanungsan menjadikan hidupnya dalam spekulasi pemaknaan yang ada, ini itu, dan seterusnya. Dengan satu dasar bagaimanapun kehidupan mereka, mereka harus tetap menjaga ajaran Pranataning Kamanungsan (pengetahuan tentang kemanusiaan) sebagai modal hidup mereka didunia. Kedua, jelas karena didorong oleh ideologi keagamaan Islam. Dan yang ketiga, secara birokrasi tidak diakui sebagai agama resmi di Indonesia.

2. Aktualisasi Ideologi Kawerub Kamanungsan melalui Lembaga Adat Osing

Meski ajaran Kawerub Kamanungsan tampak mendalam dan mengesankan bagi anggotanya, anggota Kawerub Kamanungsan masih tetap melonggarkan diri dan tidak dogmatik untuk memungkinkan tumbuhnya

78 | Lia Hilyatul Masrifah - Relasi Kuasa antara Muslim Ortodoks dan Penghayat Kaweruh Kamanungsan 
pendekatan ekumenis dan memberi ciri kehidupan tersendiri. Secara intelektual dan moral anggota Kawerub Kamanungsan lebih terlihat biasa dan tidak mencolok, seperti warga petani pedesaan yang mencukupkan diri untuk hidup sehari saja itu sudah sebuah keberuntungan. Biarpun ada yang berpendidikan tinggi dan kaya itu hanya sebagian kecil. Anggota Kawerub Kamanungsan juga tidak menghindari secara jelas dengan tetangga Muslim Ortodoks_-santri jika kita menggunakan istilah Geertz, karena mereka tetap ambil bagian dalam kegiatan-kegiatan desa yang biasa dilakukan masyarakat. Ikut berdoa dan bahkan hingga mengikuti pemakaman para orang Muslim Ortodoks.

\section{Gambar 3.}

Hubungan Lembaga Adat, Ideologi, dan Stuktur Adat

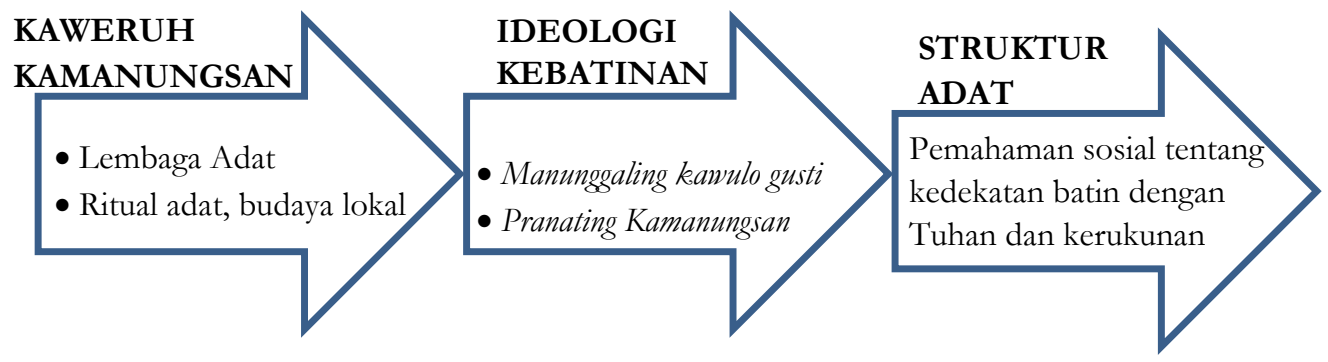

Bagi Wanita, Kawerub Kamanungsan memiliki daya tarik tersendiri bagi mereka, mereka melihat bahwa Kaweruh Kamanungsan lebih menstimulasi peranan, tidak mementingkan perbedaan, jika dibandingkan dengan Islam desa tradisional. Tidak ada segregasi yang dapat diperbandingkan mengenai jenis kelamin dan wanita tidak disingkirkan dari pengajaran maupun kegiatan. Memrioritaskan laki-laki dan kurang mengacuhkan perempuan bukan cerminan dari ajaran Kaweruh Kamanungsan, meski laki-laki berperan penuh memimpin dalam diskusi dan organisasi, wanita diinisiasi sebagai anggota penuh. Ada beberapa wanita sepuh Kawerub Kamanungsan yang dipandang sama pengetahuannya dengan suaminya, sehingga kami kerap kali dibimbing dalam diskusi yang menjelaskan tentang dunia mistik dan ajaran Kawerub Kamanungsan secara bersamaan.

Anggota dari penghayat kebatinan Kaweruh Kamanungsan sebagian melibatkan diri pada sebuah lembaga adat, dan sebagian yang lainnya 
melibatkan diri pada bagian budaya lokal dan wisata alam yang dimiliki oleh masyarakat Desa Sedoyo. Keterlibatan mereka pada budaya menjadi bentuk eksistensi mereka bahwa mereka memang masih ada dan masih berkembang. Keterbukaan mereka pada orang lain dan pendatang tentang keberadaan Kaweruh Kamanungsan menunjukkan adanya isyarat bahwa mereka ingin publik mengetahui tentang keberadaan mereka dan seperti yang terjadi pada penganut penghayat kebatinan pada umumnya, mereka secara formal mengikuti pilihan agama resmi yang ada di Indonesia.

Saya mencoba melakukan pembagian pada "lembaga adat sebagai alternatif aktualisasi ideologi Kawerub Kamanungsan" dalam dua macam (meski terlihat tumpang tindih). Jenis pertama, kebudayaan lokal dan pertunjukan. Hal ini terkait dengan cara pandang bahwa adat sebagai 'budaya' atau 'kesenian' yang hendak ditampilkan dan dipamerkan, khususnya dalam kesempatan-kesempatan penting (misalnya, pada libur nasional, kunjungan orang-orang penting dan acara rutin tahunan adat lokal). Sifatnya yang lokal dan menarik wisatawan atau pengunjung untuk mengetahui sejarah hingga proses perkembangan adat Osing itu sendiri. Kawerub Kamanungsan sebagai anggota yang terlibat dalam berbagai hal adat lokal memberikan pengetahuan kepada pengunjung atau ilmuan yang tertarik dengan adat Osing yang diselaraskan dengan pengetahuannya dalam ajaran Kawerub Kamanungsan. Jenis kedua, berkenaan dengan kebudayaan Osing dan berbagai ritual keagamaan yang ada di Sedoyo. Berkaitan dengan jenis sebelumnya tentang adat sebagai pertunjukan yang dipamerkan, Kaweruh Kamanungsan melihat peluang tersebut sebagai jembatan untuk menunjukkan eksistensinya, dengan aktif dalam lembaga adat yang mulai ramai dalam wacana saat ini, dia berusaha untuk mempengaruhi kebijakan dan sosial politik desa.

Beberapa upaya yang dilakukan Kawerub Kamanungsan dalam lembaga adat ini ialah menghidupkan kembali ritual-ritual lokal sebagai tujuan utama, dengan pertimbangan bahwa melihat banyak perubahan cara pandang, perilaku dan minimnya rasa untuk saling menghargai yang disebabkan oleh arus globalisasi. Kemudian 'adat sarasehan' yang sedang dibangkitkan dan pulihkan kembali dan praktik-praktik yang telah lama dibuang karena ketidaksetujuan pemerintahan desa dibangun kembali 
dan diperbaharui dengan cara sedemikian rupa sehingga masyarakat masih memandangnya sebagai sebuah ritual yang sungguh-sungguh lokal Osing bukan ritual Kawerub Kamanungsan.

Kaweruh Kamanungsan yang dikucilkan sebagai sebuah identitas keagamaan lokal, sekalipun beberapa dari keanggotaan telah memiliki pendidikan yang memadai tidak mampu ikut masuk pada pemerintahan desa. Sebagai contoh, saat pemilihan kepala desa tahun lalu ada salah satu anggota Kawerub Kamanungsan mencalonkan diri sebagai kepala desa, namun tak mampu menentang arus perpolitikan dikadik dan magis yang telah mengakar dalam masyarakat Osing. Hingga anggota Kaweruh Kamanungsan berupaya dalam mencitrakan dirinya yang berkeinginan menempatkan Kawerub Kamanungsan sebagai ajaran keagamaan yang sifatnya individu melainkan mampu dijadikan ajaran dan aturan hidup yang sifatnya positif. Adat lokal seperti buyut, cili, ider bumi dan moco lontar menjadi bagian penting pada penduduk Sedoyo, serta dianggap efektif dalam memberikan nilai-nilai lokal dan norma-norma sosial. Seperti yang biasa dilakukan oleh pak adi, Ideologi yang dimunculkan dalam sikap keseharian pak adi memperlihatkan bahwa sikap dia dan buah dari pikirannya tidak lepas dari ajaran Kawerub Kamanungsan, dengan melihat apa yang terjadi pada individu-individu yang hidup di dalam ideologi, yaitu representasi tetap atas dunia (agama, etika, dan sebagainya) dengan distorsi imajiner yang bergantung pada hubungan imajiner mereka terhadap kondisi-kondisi eksistensinya, atau dengan kata lain, pada relasi-relasi produksi dan relasi-relasi kelas $($ ideologi $=$ relasi imajiner atas relasi-relasi nyata). ${ }^{16}$ Menunjukkan bahwa sikap dari seseorang tidak pernah lepas dari ideologi, tidak hanya seperangkat ide melainkan juga ditunjukkan dalam praktik kehidupan keseharian seseorang. Pak adi sebagai seseorang yang sering ditunjuk sebagai pamong budaya, melalui sikapnya dia akan mudah mempengaruhi seseorang dalam menilai sebuah realitas kehidupan. Sebagai contoh tentang ajaran kerukunan Kaweruh Kamanungsan, dia menjelaskan dengan bahasa dan perumpamaan yang mudah dipahami dan mudah dimengerti.

${ }^{16}$ Althusser, Tentang Ideologi, 35. 


\section{Analisis Kemapanan Ideologi Islam dan Kaweruh Kamanungsan}

Ada dua persamaan aspek yang ada di dalamnya, masing-masing adalah aspek vertikal dan horizontal. Kedua aspek yang ada dalam kemajemukan masyarakat Sedoyo tersebut mengandung maksud bahwa Muslim Ortodoks dalam keterlibatannya pada pemerintahan desa mampu memberikan hubungan yang simbiosis mutualisme. Secara vertikal muslim Ortodoks bisa mengontrol kebijakan desa sesuai dengan kepentingannya. Secara horizontal pun muslim bisa melibatkan dirinya pada kegiatan ritual adat dan sosial keagamaan. Sehingga secara vertikal maupun horisontal muslim lebih memiliki ruang lebih dalam mengaktualisasikan ideologi melalui lembaga masyarakat yang ada dan seperti tujuan yang telah disebutkan pada bagian sebelumnya.

\section{Gambar 4.}

Kemajemukan masyarakat, Kawerub Kamanungsan dan Muslim dalam keterlibatannya

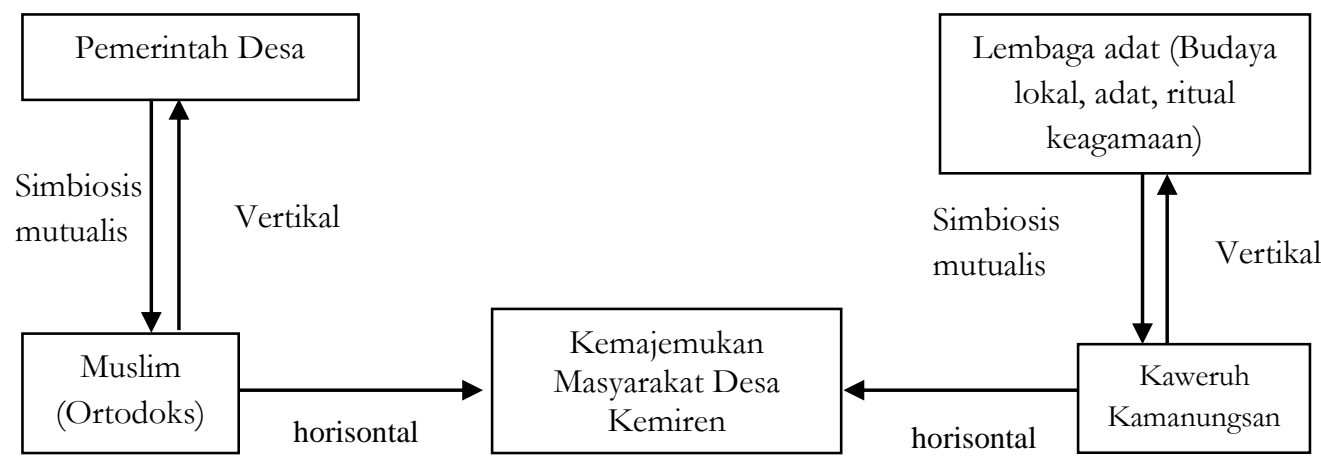

dengan lembaga pemerintahan (vertikal) dan lembaga adat (horisontal)

Kaweruh Kamanungsan yang hanya memiliki ruang pada lembaga adat, kebenarannya ialah keberadaan Kawerub Kamanungsan secara institusional tidak diterima sebagai sebuah Ideologi atau ajaran keagamaan, tetapi, Kawerub Kamanungsan bisa diterima sebagai paham etika, masyarakat Sedoyo menerima pemahaman tentang Kaweruh Kamanungsan tentang kehidupan, etika dalam bersosialisasi dengan individu lainnya serta dalam pengetahuannya tentang adat lokal. Kaweruh

82 | Lia Hilyatul Masrifah - Relasi Kuasa antara Muslim Ortodoks dan Penghayat Kaweruh Kamanungsan 
Kamanungsan yang mampu diterima secara moral-etika akan menjembatani perbedaan yang ditimbulkan oleh faktor-faktor keagamaan atau kultur dengan mengurangi kesenjangan yang ditimbulkan oleh faktor-faktor tersebut. Sehingga dalam keterlibatannya pada lembaga adat, Kaweruh Kamanungsan lebih mudah mengorganisir secara pemikiran dan tindakan yang bisa diterima masyarakat serta dipahami.

Pak Ahmad misalnya, dia mampu melegalisasikan ajaran kerukunannya dalam setiap acara yang dia pimpin. Sebagai sosok yang karismatik, pengetahuan tentang tradisi lokal serta memiliki nilai-nilai keagamaan yang matang, di setiap momen penting seperti slametan tempat di mana semua lapisan masyarakat berkumpul dengan landasan gotong royong tanpa pembedaan agama, dia dengan sikapnya mencontohkan kepada mereka yang awam, sesekali dalam obrolan ringan menjelaskan tentang pemahaman Kawerub Kamanungsan dengan lawannya. Tanpa berharap untuk Kaweruh Kamanungsan mendapatkan anggota baru tetapi lebih pada sebuah tujuan untuk memperbaiki etika satu sama lain, karena dirasa telah banyak yang mulai melupakan pentingnya etika dan moral dalam kehidupan sosial.

Konsep Kerukunan Kawerub Kamanungsan dijadikan sebagai sesuatu yang merupakan 'kebiasaan' atau 'budaya' yaitu tindakan-tindakan yang dimaksudkan untuk mendorong ikatan sosial dan bukan merepresentasikan keyakinan keagamaan semata. Tetapi, melalui lembaga adat, kemapanan ideologi kerukunan Kawerub Kamanungsan ini mampu membawa masyarakat melihat bahawa ajaran Kaweruh Kamanungsan kepada pemberdayaan diri dan membawa kepada aras yang lebih positif. Legitimasi-legitimasi lokal digunakan sebagai alat pengaruh kuat dalam kebijakan lembaga adat. Pandangan-pandangan yang bermuatan Ideologis mudah dicatat dan dipahami dalam kehidupan, bisa jadi ini karena masyarakat yang terlihat masih 'awam' sehingga mereka mudah terbuka dengan orang asing atau ada tujuan lain yang mereka mudah dimasuki oleh pendatang dari luar desa. Setiap Individu yang berperilaku dengan cara tertentu, mengadopsi sikap praktis tertentu, ditambah lagi dengan berperan serta dalam praktik-praktik berkala tertentu merupakan 
pelbagai praktik aparatus ideologi, yang padanya ide 'bergantung. ${ }^{17}$ Akhirnya adanya penilaian yang bermuatan ideologis tanpa ada toleransi pada sebuah perbedaan karakter 'bawaan' natural yang dimiliki manusia, terlepas dari pembentukan sikap dari lingkungan dan agama itu pun terjadi. Dicontohkan Althusser dengan individu yang dengan penuh kesadaran, dirinya memilih secara bebas untuk berperan sebagai subjek. Jika ia percaya kepada Tuhan, ia pergi ke gereja untuk menghadiri misa, berlutut, berdoa, membuat pengakuan dosa, menjalankan penebusan dosa (yang tentunya bersifat material, dalam pengertian umum dari terminologi gerejawi), bertobat, dan seterusnya. Jika ia percaya pada kewajiban, ia akan memiliki sikap-sikap yang koresponden dengan apa yang tertulis dalam praktik-praktik ritual 'menurut prinsip-prinsip yang benar'. Jika ia percaya pada keadilan, ia akan tunduk tanpa syarat dan aturan-aturan hukum yang berlaku, menyuarakan protes jika aturanaturan tersebut dilanggar, menandatangani petisi, mengadakan demonstrasi dan lain-lain. ${ }^{18}$

Pemahaman Kawerub Kamanungsan sebagai ajaran tentang "Kaweruh Kamanungsan" yakni pengetahuan tentang kemanusiaan, sebagian muncul merupakan politik keagamaan karena Jawanisme tetap hidup dalam Indonesia dan modern dengan tetap bersikap tak mau menonjolkan diri (low profile) dibawah konstitusi hanya agama-agama dunia yang diakui sebagai agama, akan tetapi "humanisme" yang melekat pada sekte sebenarnya lebih tua dari republik itu sendiri; buku pegangan tentu memiliki rubrik yang sama, dan kebanyakan anggota Kawerub Kamanungsan tidak menaruh rasa benci kepada orang-orang yang tak mengakui merek, mereka cukup keberatan atas perlakuan agama-agama resmi bukan karena ingin disejajarkan dalam kategori yang sama, agama adalah bagi persoalan eksternal, kehidupan keduniaan manusia dalam rangka menjalankan tugas dan tunduk pada aturan-aturan dan sanksi hukuman-kehidupan sekuler, demikian kata orang. Selain itu agama juga ditandai pula oleh konsep-konsep yang bertentangan sebagaimana pemahaman kabur mengenai kehidupan setelah mati, "Humanisme" dipihak lain, memenuhi dimensi spiritual mendalam, yakni dalam

\footnotetext{
${ }^{17}$ Ibid., 47.

18 Ibid., 55
}

84 | Lia Hilyatul Masrifah - Relasi Kuasa antara Muslim Ortodoks dan Penghayat Kaweruh Kamanungsan 
kehidupan itu sendiri. Sehingga pemahaman ideologi itu akan lebih melekat dan mengakar pada pola masyarakat. Simpel tetapi efektif dalam menanamkan ideologi atau memberikan pemahaman ideologi Kaweruh Kamanungsan pada masyarakat.

Ideologi yang bisa digunakan sebagai dasar solidaritas untuk melakukan perubahan serta mencapai tujuan menjadi sering digunakan. Islam yang memiliki otoritas besar dalam pemerintahan desa, memberikan kebijakan-kebijakan yang sifatnya Islami tanpa menghiraukan perbedaan kepercayaan lain. Contohnya ialah saat adanya ritual nyekar buyut cili penghapusan ritual adat secara konstitusional, ideologi Islam yang melarang untuk melakukan hal-hal yang di luar syariah dimasukkan sebagai keputusan besar dengan dalih demi kepentingan bersama. Sisa-sisa dari kepercayaan terdahulu ini dikhawatirkan syirik, karena banyak dari masyarakat ini meminta permohonan secara berlebihan di makam leluhur. Awalnya elit agama yang ada di Sedoyo sedikit memberikan kelonggaran karena menghargai jika makan itu dia sakralkan dengan alasan menghormati leluhur, tetapi berjalannya waktu ternyata sebagian masyarakat sudah melebihi dari sekedar menghormati, saat mereka akan melakukan sebuah acara mereka nyekar dan meminta pertolongan. Hal tersebut meresahkan sehingga dalam tahun 2005 pemerintahan desa memberikan kebijakan yang bermuatan Ideologis Islam agar masyarakat tidak lagi mengadakan ritual adat tersebut.

Beberapa kebijakan pemerintahan desa tidak sesuai dengan kepercayaan lokal sempat mendapat protes dari masyarakat awam yang lebih kejawen dan Kaweruh Kamanungsan, tetapi hal itu tidak berlangsung lama karena otoritas yang dimiliki elite keagamaan Islam sangat luas, secara vertikal di menguasai ruang pemerintahan desa dan horizontalnya dia tetap memiliki masa Islam yang mayoritas.

\section{Penutup}

Dalam artikel ini dapat kita pahami bagaimana pengaruh ideologi dan keyakinan mempengaruhi keterlibatan penghayat kebatinan Kawerub Kamanungsan dengan muslim Ortodoks dalam struktur kelembagaan Desa 
Sedoyo. Adanya koherensi internal yang mempengaruhi perbedaan keterlibatan keduanya. Pertama, di Desa Sedoyo terdapat dua lembaga Desa yang memiliki pengaruh kuat dalam kehidupan masyarakat Sedoyo, yaitu Pemerintahan Desa dan Lembaga adat. Pemerintahan Desa memiliki program kerja yang telah terorganisir melalui peraturan daerah dan telah ditetapkan oleh Negara secara Nasional sehingga program pengembangan Desa telah ada dalam peraturan daerah, jika ada yang berbeda itu sedikit dan hal itu karena disesuaikan dengan kebutuhan daerah Sedoyo dan berkaitan tentang budaya lokal Sedoyo. Lembaga adat memiliki peran yang kuat sebagai sebuah wadah dalam suatu masyarakat yang dikenal sebagai Desa Adat Osing Banyuwangi.

Kedua, Sedoyo memiliki pola hubungan kliental elite lokal yang diadik dan magis masih mengakar yang tidak mampu dicairkan oleh pola hubungan yang rasionalis dan pragmatis. Dengan menggunakan identitas agama sebagai identitas kolektif yang mendapat dari legitimasi politik mampu membedakan dan memecahbelahkan pada pergulatan politik antara Kawweruh Kamanungsan dan Muslim dalam struktur kelembagaan. Dalam sejarah panjang antara Kawerub Kamanungsan dan Muslim membentuk suatu aliran sosio-politik yang ada dalam struktur desa. Secara ringkas bahwa dengan adanya ideologi yang berbeda mampu memecahbelahkan sektor-sektor politik antara keduanya. Struktur kelembagaan dijadikan arena kontestasi Ideologi oleh keduanya. Dalam pendidikan sekolah dasar kebijakan sekolah yang didukung oleh kebijakan desa mewajibkan bagi siswanya untuk bisa membaca Alquran dan mengenakan seragam yang menutup aurat, pegawai yang ada dalam pemerintahan desa dan guru perempuan pun dianjurkan untuk menggunakan jilbab pada kerja. suatu muatan ideologis 'islamis' yang diberikan dalam pendidikan akan lebih efektif dan positif. Sedangkan Kaweruh Kamanungsan dalam lembaga adat memiliki pengaruh penting dalam memberikan pemahaman ideologinya, dengan masuk pada acara adat dan ritual keagamaan mampu mencitrakan dirinya dengan ideologinya guna mengaktualisasikan tentang keberadaan kepercayaan Kawerub Kamanungsan. Sama halnya pada anggota Kawerub Kamanungsan yang berpengaruh dalam lembaga adat memberikan pengertian tentang kerukunan pada setiap momentum yang dijadikan sebuah 'kebiasaan' atau 'budaya' yaitu tindakan-tindakan yang dimaksudkan untuk

86 | Lia Hilyatul Masrifah - Relasi Kuasa antara Muslim Ortodoks dan Penghayat Kaweruh Kamanungsan 
mendorong ikatan sosial dan bukan merepresentasikan keyakinan keagamaan semata.

Ketiga, secara ringkas bahwa, Muslim dalam pemerintahan Desa menggunakan ideologi 'islamis' dalam semua kebijakan, dan Kawerub Kamanungsan dalam lembaga adat menggunankan ideologi 'manunggaling kawulo gusti dan pranataning kamanungsan' dalam setiap momen budaya maupun keseharian. Kerap kali kita tahu bahwa Islam yang memiliki legitimasi kuat baik secara vertikal (pemerintahan) dan horizontal (sosial) mampu mengalihkan kepercayaan-kepercayaan lokal yang minoritas. Kawerub Kamanungsan yang secara birokrasi tidak diakui sebagai agama menggunakan pendekatan horizontal (sosial) dalam menjembatani perbedaan yang ditimbulkan oleh faktor-faktor keagamaan atau kultur dengan mengurangi kesenjangan yang ditimbulkan oleh faktor-faktor tersebut.

\section{Daftar Pustaka}

Althusser, Louis. Tentang Ideologi: Marxisme Strukturalis, Psikoanalisis, Cultural Studies. Yogyakarta: Jalasutra, 2008. 2003. . Ideological State Aparatus. New York: W.W. Norton and Co,

Beatty, Andrew. Variasi Agama di Jawa. Jakarta Raja Grafindo Persada, 2001.

Bellah, Robert N. Beyond Belief: Esei-Esei Agama di Dunia Modern, terjemahan. Jakarta: Paramadina, 2000.

Bottomore, Tom B. "Kelas, Elite dan Masyarakat". Dalam Sartono Kartodirdjo (ed.), Kepemimpinan dalam Dimensi Sosial. Jakarta: LP3ES, 1990.

Bungin, B. Analisis Data Penelitian Kualitatif. Jakarta: Rajagrafindo Persada, 2003.

Geertz, Clifford. Interpretation of Cultures. New York, NY: Basic Books, 1973. 
. Islam Observed: Religious Development in Morocco and Indonesia. Chicago: University of Chicago Press, 1971. 1976.

. The Religion of Java. Chicago: University of Chicago Press,

Djailani, Abdul Qadir. Perjuangan Ideologi Islam di Indonesia. Jakarta: pedoman Ilmu Jaya, 1996.

Djokosurjo dkk. Agama dan Perubahan Sosial, Yogyakarta: LKPSM, 2001.

Ferretter, L. Louis Althusser. Oxford: Routledge, 2006.

Goffman, E. The Presentation of Self in Everyday Life. New York: Anchor Book, 1959.

Hefner, Robert W. Hindu Javanese: Tengger Tradition and Islam. Princeton NJ: Princeton University Press, 1985.

Henry D. Aiken. Abad Ideologi . Yogyakarta: Bentang, 2002.

Howell, Julia Day. "Muslim, the New Age and Marginal Religions in Indonesia: Changing Meaning of Religious Pluralism". Dalam Social Compass 52: 473-93, 2005.

Ida, Laode. Anatomi konflik: NU, Elit Islam dan Negara. Jakarta: Pustaka Harapan, 1996.

Jackson, Karl D. Kewibawaan Tradisional, Islam, dan Pemberontakan (Kasus Darul Islam Jawa Barat). Jakarta: Pustaka Utama Grafitti, 1990.

Jamil, Abdul dkk. Islam dan Kebudayaan Jawa. Yogyakarta: GAMA Media, 2000.

Kholiludin, Tedi. Kuasa Negara atas Agama: Politik Pengakuan, Diskursus 'Agama Resmi', dan Diskriminasi Hak Sipil. Semarang: Rasail Media Group, 2009.

Kleden, Ignaz. Dari Etnografi ke Etnografi tentang Etnografi: Antropologi Clifford Geertz dalam Tiga Tahap. Jogyakarta: LKiS, 1998.

Larain, Jorge. Konsep Ideologi. Yogyakarta: LKPSM, 1996.

Leland, David Mc. Ideologi Tanpa Akhir, terj. Muhammad Syukri. Yogykarta: Kreasi Wacana, 2005.

88 | Lia Hilyatul Masrifah - Relasi Kuasa antara Muslim Ortodoks dan Penghayat Kaweruh Kamanungsan 
Maliki, Zainuddin. Sosiologi Politik: Makna Kekuasaan dan Transformasi Politik. Yogyakarta: Gadjah Mada University Press, 2010.

Mudzhar, M. Atho. Pendekatan Studi Islam dalam Teori dan Praktik. Yogyakarta: Pustaka Pelajar, 2002.

Mulder, Niels. Agama, Hidup Sehari-hari dan Perubahan Budaya. Jakarta: Gramedia Pustaka Utama, 1999.

Muzani. Persoalan Agama Interen Umat. Bandung: Mizan, 1991.

Northcott, Michael. C. "Persepektif Sosiologis". Dalam Peter Connolly (ed.), Aneka Perspektif Studi Agama. Jogjakarta: LkiS, 2002.

Patria, Nezar. Antonio Gramsci Negara \& Hegemoni. Yogyakarta: Pustaka Pelajar, 1999.

Ricklefs, M.C. Mystic Synthesis in Java: a History of Islamization from the Fourteenth to the Early Nineteenth Centuries. Norwalk CT: East Bridge, 2006.

Ritzer, Goerge. Sociological Theory New York: McGraw-Hill Inc, 1992.

Roger, Simon. Gagasan-gagasan Politik Gramsci. Yogyakarta: Pustaka Pelajar, 2004.

Rosyid, Harun Nur dkk. Pedoman Pelestarian Kepercayaan Masyarakat. Jakarta: Proyek Pelestarian dan Pengembangan Tradisi dan Kepercayaan, Kementerian Kebudayaan dan Pariwisata, 2004.

Russell, Bertrand. Kekuasaan: Sebuah Analisis Sosial Baru. Jakarta: Obor, 1988.

Sofyan, Ridin. Menguak Seluk Beluk Aliran Kebatinan. Semarang: Aneka Ilmu, 1999.

Sohatono, Irawan. Metode Penelitian Sosial, Bandung: Remaja Rosdakarya, 1999.

Steenbrink, Karel A. "The Pancasila Ideology and an Indonesian Muslim Theology of Religions". Dalam Jacques Waardenburg (ed.), Muslim Perception of Other Religions. New York, NY: Oxford University Press, 1999. 
Suara Merdeka. Jumlah Penghayat Kepercayaan 8,8 Juta. 24 Maret 2009. http://www.suaramerdeka.com/harian/0505/02/pan17.htm

Subagya, Rahmat. Kepercayaan dan Agama. Yogyakarta: Kanisius, 1984.

Suratman. Perubahan Orientasi Keagamaan: Sebuah Studi Kasus (TesisUniversitas Indonesia, 1986).

Zainuddin, Sodaqah dkk. Orientasi Nilai Budaya Osing di Kabupaten Banyuwangi. Jember: Lembaga Penelitian Universitas Jember, 1996. 